\title{
Sosyal Demokrat Refah Devletlerinde Çocuklara Yönelik Sosyal Koruma İstatistiklerinin İncelenmesi
}

\author{
ERCEM ERKUL
}

\section{Özet}

Sosyal demokrat refah devletlerinin uyguladıkları politikaların, Anglosakson ve Muhafazakâr refah devletlerine göre daha hak temelli, daha kamusal ve daha evrensel programlara sahip olduğu söylenebilir. Bu sosyal politikaların ve programların odağında çocuklar bulunmaktadır ve bu politikalar ve programların sonuçları da çocuklara yönelik istatistiklerdir. Bu istatistikler çocuk ve aile refahına ilişkin önemli bilgiler sunmaktadır. Bu bağlamda çalışmanın amacı, sosyal demokrat refah devletlerinde çocuk ve aile refahına ilişkin sosyal harcama, çocuk yoksulluğu, sosyal dişlanma ve maddi yoksunluk istatistiklerinin incelenmesidir. Sonuç olarak, sosyal demokrat refah devletlerinin aile ve çocuğa yönelik uyguladıkları programların, çocuk yoksulluğu istatistiklerine olumlu etkisi olduğu söylenebilir.

Anahtar kelimeler: Sosyal Koruma, Çocuk Yoksulluğu, Sosyal Dışlanma, Çocuk Bakımı, Sosyal Hizmet, İskandinavya, Sosyal Demokrat Refah Devleti
Abstract

It can be said that the policies implemented by the social democratic welfare states have more rights-based, public and universal programs than the AngloSaxon and Conservative welfare states. Children are at the center of these 
social policies and programs, and the results of these policies and programs are statistics children. These statistics provide important information in understanding child and family welfare. The aim of this study is to examine the reflections of social democratic welfare states on social spending, child poverty, social exclusion and material deprivation statistics related to child and family welfare. As a result, it can be said that the programs implemented by the social democratic welfare states on families and children have a positive effect on children's statistics.

Keywords: Social Protection, Child Poverty, Social Exclusion, Child Care, Social Work, Scandinavia, Social Democratic Welfare State

\section{Giriş}

Üretim faktörleri, toprak ve doğal kaynaklar, emek ve sermaye olmak üzere sınıflanmaktadır. 20.yüzyılın son çeyreği ile beraber teknolojik atılımlar ve ilerlemelerin hızlı bir şekilde artması nedeniyle üretim faktörleri dönüşmektedir. Bu dönüşüme ve evrimleşmeye öncül olan şirketler ve ülkeler daha büyük atılımlar gerçekleştirmektedir. Söz konusu bu duruma ayak uydurmaya çalışan ya da bununla mücadele etmeye çalışan ülkeler ve şirketler yeni düzene alışmakta zorlanmaktadır. 20. yüzyıldaki bu dönüşümü Harari (2019, s.21) kitabının “Uyanış” bölümünde şu şekilde analiz etmiştir:

“İnsanlar bulgular, sayılar veya denklemlerden ziyade anlatılar üzerinden düşünür ve anlatı ne kadar basitse o kadar iyidir. Her insanın, grubun ve milletin kendi öyküleri ve mitleri vardır. Fakat 20. yüzyılda New York, Londra, Berlin ve Moskova'da dünyaya şekil veren seçkinler tüm dünyanın geçmişini açıklama ve geleceğini öngörme iddiası taşıyan üç büyük anlatı formüle ettiler: faşist anlatı, komünist anlatı ve liberal anlatı. II. Dünya Savaşı faşist anlatıyı devirdi ve 1940'ların sonlarından 1980'lerin sonlarına kadar dünya sadece iki anlatının savaş alanıydı: komünizm ve liberalizm. Sonra komünist anlatı çöktü ve liberal anlatı baskın bir biçimde, en azından dünya çapındaki seçkinlere göre, insanlığın geçmişine rehber ve dünyanın geleceğinin olmazsa olmaz kılavuzu haline geldi."

İkinci Dünya Savaşı'ndan sonra Batı Avrupa ülkeleri toplumsal uzlaşmayı sağlamak, refah toplumuna ulaşmak ve sosyal devlet seviyesine gelmek için birçok engeli aşmıştır. Söz konusu bu durumu sürdürmeleri de hiç kolay değildir. Toplumsal uzlaşma adı altında bahsedilen durum, gelişmiş bir endüstri sektörü, büyük miktarda sermaye birikimi ve yoğun bir "ücretli çalışan"dan oluşan ve endüstri toplumunu oluşturan toplumsal bir sınıfı 
tarif etmektedir. Savaştan önce bu sınıflar çatışma halindeyken, savaş sonrası dönemde demokrasi mekanizmaları ile birlikte bu durum uzlaşmaya dönüşmüştür (Koray, 2012, s.60). 1945-1973 yılları refah devletlerinin altın çağını yaşadığı dönem olarak kabul edilmekte olup yoksulluğun giderilmesi, işsizliklerin istihdama dahil edilmesi ve kitlesel olarak dezavantajlı grupların toplumsal refahlarının iyileştirilmesi bu döneme rastlamaktadır (Şenses, 2014, s.46).

Buğra (2015, s.65), Büyük Buhran ve ardından gerçekleşen İkinci Dünya Savaşı'nın yol açtığı toplumsal yıkım ve insani acıların yerini emeğin artık bir meta olmaktan çıktığı ve toplumsal bütünlüğü sağlamak üzere sosyal politikaların öncelendiği bir anlayışın aldığını ifade etmiştir. Aslında "bırakınız yapsınlar, bırakınız geçsinler" görüşü devletler tarafından terkedilmiştir. Bu doğrultuda en başta sağlık, eğitim, sosyal güvenlik alanları olmak üzere devlet kamu hizmetlerini artırmıştır. Devletler, eskiden olduğu gibi bireyleri soyut bir nesne olarak görmeyip, somut olarak ele alma gereği duymuştur. Buna ek olarak, devletler bireylerin sosyo-ekonomik durumlarını geliştirme ve iyileştirme ile insan hakları temelli, eşitlikçi ve özgürlükçü anlayışı benimsemeleri yönünde politikalar uygulamaya başlamıştır (Koray, 2012, s.62-70). Ancak bu gelişmeler ve iyileştirmeler kolay olmamıştır. Önce sermaye sınıfının, sonra da işçi sınıfının vermiş oldukları mücadele, demokrasinin ve insan haklarının daha iyi seviyeye gelmesine katkıda bulunmuştur (Koray, 2012, s.65). Bu bağlamda refah devleti kavramı ortaya çıkmış ve olgunlaşmaya başlamıştır.

Refah devleti kavramını hem dar hem de geniş anlamda anlatan yaklaşımlar mevcuttur. Daha dar bakış açısına sahip olanlar, refah devleti kavramına geleneksel sosyal iyileştirme (düzeltme) açısından yaklaşırlar: Gelir transferleri ve sosyal hizmetler, dahası konut sorununu da değinmişlerdir. Daha geniş görüş açısına sahip olanlar ise çoğunlukla politik iktisat açısından sorularını çerçevelemekle birlikte ilgileri devletin ekonomiyi yönetme ve örgütlemedeki daha büyük rolüne odaklanma yönündedir. Bu nedenle daha geniş bir bakış açısına sahip olanlar; istihdam, ücretler ve genel makroekonomik yönlendirme sorunlarını refah devleti kompleksinin ayrılmaz bileşenleri olarak kabul etmektedir. Bir bakıma, bu yaklaşım konusu 'Keynesyen refah devleti' ya da 'refah kapitalizmi' olarak tanımlanmaktadır (Esping-Andersen, 1990, s.1-2). Esping-Andersen, sosyal haklar ve refah devleti katmanlaşmasındaki uluslararası farklılıkları araştırırken, devlet, piyasa ve aile arasında niteliksel olarak farklı düzenlemelere ilgi çekmiş ve bu nedenle refah 
devleti varyasyonlarını doğrusal olarak dağıtmamış ve rejim türlerine göre kümelemiştir (Esping-Andersen, 1990, s. 26).

Birinci kümede, bütçe hesaplı yardımlar, mütevazi evrensel transferler (yardımlar) veya mütevazi sosyal sigorta planlarının baskın olduğu 'liberal refah devletleri' görülmektedir. Devlet ya pasif olarak yalnızca asgari düzeyde garanti vererek ya da aktif olarak özel refah programlarını sübvanse ederek piyasayı teşvik etmektedir. Bu sınıflamaya ABD, Kanada ve Avustralya gibi ülkeler örnek verilebilir. Avusturya, Fransa, Almanya ve İtalya gibi ülkeler ise ikinci rejim tipi kümelemeye girmektedir. Bu kümedeki ülkeler, tarihsel korporatist-devletçi mirasını, yeni 'sanayi-sonrası' sınıf yapısına hitap edecek şekilde güncellemiştir. Korporatist rejimler tipik olarak Kilise tarafından şekillendirilmekte olup bu nedenle geleneksel ailelerin korunmasına büyük önem vermektedir (Esping-Andersen, 1990, s.26-27).

Üçüncü ve açıkça en küçük rejim kümesi, evrenselcilik ve sosyal haklar ilkelerinin yeni orta sınıflara da genişletildiği ülkelerden oluşmaktadır. Buna ‘sosyal demokrat' rejim türü denilmektedir. Bunun nedeni ise, ülkelerde sosyal demokrasinin açıkça toplumsal reformun arkasındaki baskın güç olmasıdır. Sosyal demokratlar, devlet ile piyasa ya da işçi ile orta sınıf arasında bir düalizme neden olacak uygulamaları tercih etmek yerine, en yüksek standartların eşitliğini sağlayacak bir refah devlet yolunu seçmişlerdir. Böylece, mavi yakalılar, beyaz yakalıların veya memurların haklarıyla eşitlenmiş ve aynı haklara sahip olmuştur; tüm katmanlar tek bir evrensel sigorta sistemi altında birleştirilmiştir, ancak yardımlar alışılmış kazançlara göre derecelendirilmektedir. Sonuç olarak refah devleti lehine esasen evrensel bir dayanışma inşa edilmektedir. Sosyal demokrat rejimin kurtuluş politikası hem piyasaya hem de geleneksel aileye hitap etmektedir. Korporatist yerellik modelinin aksine, ilke ailenin yardım kapasitesi tükenene kadar beklemek değil, aile maliyetlerini önleyici olarak sosyalleştirmektir. Buna ek olarak, ideal olan, aileye bağımlılığı en üst düzeye çıkarmak değil, bireysel bağımsızlık kapasitelerini artırmaktır. Bu anlamda model, liberalizmin ve sosyalizmin tuhaf bir birleşimidir. Sonuç, doğrudan çocuklara transfer sağlayan ve çocukların, yaşlıların ve çaresizlerin doğrudan bakımını üstlenen bir refah sistemidir (Esping-Andersen, 1990, s.27-28).

Çocuk ve Medeniyet 2020/1
Sosyal demokrat refah devletleri uyguladıkları politikalar ile geçmiște bu politikaların olumlu dönüşlerini almıştır. Blakely (1992, s.250)'ye göre aile yapısındaki değişiklikler, sanayileşmiş ülkelerde en önemli 
yoksulluk nedenlerinden biri olarak ortaya çıkmaktadır. Reisleri kadın olan hane halkları içinde çocukların durumunun ülkeler arasında önemli farklılıklar gösterdiğini ifade etmiştir. Örneğin; bu ailelerdeki çocukların durumu ABD ve Avusturalya'da, İsveç ve Danimarka'ya kıyasla daha kötü olduğunu gözlemlemiştir (Şenses, 2014, s.171-172). Diğer bir çalışmada ise, Pissrides (1991, s.207) konjonktürel dalgalanmaların etkilerinin ülkeden ülkeye önemli farklılıklar gösterdiğini ifade etmiştir. Resesyonun yoksulluk üzerindeki etkisinin, Avustralya ve İngiltere'de işsizlik, ABD'de ise düşük ücretler yoluyla gerçekleştiğini ancak devletin uyguladığı transfer programlarının kapsam ve etkinliği karşısında İsveç’te "hemen hemen hiç" hissedilmediği sonucuna varmış olup ekonominin gerileme dönemlerinde ortaya çıkan yoksulluğu hemen hemen bütünüyle bertaraf edebildiğini belirtmiştir (Şenses, 2014, s.201,233).

Özellikle ekonomik krizlerde, doğal afetlerde, savaşlarda vb. gibi ülkeleri derinden sarsan olaylarda ilk etkilenen nüfus grubu çocuklardır. Çocuklar bu gibi durumların olumsuz etkilerini en başta sağlık ve eğitim hizmetlerine erişememede görürler. Sonuçlarında ise yoksulluk, yoksunluk ve sosyal dışlanmayla karşılaşabilirler. Bu bağlamda, çocuklar yoksulluğun, yoksunluğun ve sosyal dışlanmanın getirdiği zorluklarla mücadele etmek zorunda kalabilir ve onların getirdiği olumsuz etkileri yıllar boyunca üzerlerinde taşıyabilirler.

Yoksulluk, çocukların zihinlerinde ve bedenlerinde yaşam boyu hasara neden olabilecek etkilere sahiptir. Bu durum çocukların yaşamı boyunca önüne çıkacak fırsatları ve insani becerilerini kısıtlayabilmektedir. Çocukluk boyunca kötü beslenmekten dolayı oluşan hasar, hastalık ve yetersiz bakım, ilerleyen yaşlarda onarılamayan fiziksel gelişime ve öğrenmemeye neden olmaktadır. Devamında onların da çocuklarının yaşamları yoksulluk içinde geçmekte ve yoksulluk içinde yaşayan çocuklar döngüyü devam ettirmektedir (UNICEF, 2001, s.1). Bu bağlamda yoksulluk döngüsü çocukların yaşamlarının tüm aşamalarını olumsuz etkilemektedir. Yetersiz bakım ve beslenme, sağlıksız çevre ile birleştiğinde solunum yolu enfeksiyonlarına, ishale ve genellikle beş yaşın altındaki çocukları öldüren diğer önlenebilir hastalıklara neden olmaktadır. Bu sorunlar çocukların fiziksel, psikososyal ve bilişsel kapasitelerini zayıflatmaktadır (UNICEF, 2001, s.1).

141

Çocuk ve Medeniyet 2020/1
Çocuklar toplumun yapı taşıdır. Bu bağlamda devletlerin çocuklara yönelik koruyucu ve önleyici tedbirler alması önemlidir. Sosyal demokrat refah devletleri, çocuklar kötü duruma düşmeden, üstelik çok daha iyi şartlarda 
yaşayabilmesi için destekleyici yardımlar ve hibeler vermektedirler. Buna ek olarak, devletlerin aileyi de destekleyici programları mevcuttur. Bu bağlamda çalışmanın amacı sosyal demokrat ülkelerin uyguladı̆̆ı programların sosyal harcama, çocuk yoksulluğu, sosyal dışlanma ve maddi yoksunluk istatistiklerine yansımalarının incelenmesidir. Bu kapsamda, 1. Bölümde sosyal demokrat refah devletlerinin çocuğa ve aileye yönelik programlarına yer verilmiştir. 2. Bölümde ise sosyal demokrat ülkelerin çocuk refahına ilişkin sosyal harcama, çocuk yoksulluğu, sosyal dışlanma ve maddi yoksunluk istatistiklerine yer verilmiştir. Son bölümde tüm bu gelişmeler ışığında tartışma gerçekleştirilmiştir.

\section{Sosyal Refah Devletlerinde Çocuğa ve Aileye Yapılan Yardımlar, Hibeler ve Destekler}

Bu bölümde sosyal demokrat refah devletlerinde çocuğa ve aileye yapılan yardımlar, ödenekler ve hibeler ele alınacaktır.

\subsection{Danimarka}

\subsection{1.Çocuk Yardımı}

Bu bölüm Avrupa Komisyonu (European Commission, 2019a, s.6-14) tarafindan hazırlanan "Your social security rights in Denmark" (Danimarka'da sosyal güvenlik haklarınız) isimli rapordan derlenmiştir.

Danimarka'da yaşayan ebeveynler ve çocuklar, aile yardımını (børnecheck) diğer bir değişle çocuk ve gençlik yardımı parasını (børne-og ungeydelsen) doğrudan alabilmektedir. Yardımlar, Udbetaling Danmark Kamu Yardım Kurumu tarafından yönetilir. Udbetaling Danmark, bir dizi kamu yardımının toplanması, ödenmesi ve kontrolünden sorumlu otoritedir (Borger, 2020). Söz konusu bu yardımı alabilmek için aşağıdaki şartları taşımak yeterlidir:

- Danimarka'da yaşamak;

- Danimarka'da tamamen vergi mükellefi olmak;

- Çocuğun 18 yaşın altında olması;

- Çocuğun Danimarka'da ikamet etmesi (yurt dışında uzun süre ikamet etmesi durumunda Udbetaling Danmark ile temasa geçilmeli);

- Çocuğun devlet tarafından desteklenmemesi;

- Çocuğun evli olmamasıdır.

Çocuk ve gençlik yardım ödeneğinden alınabilecek olan miktar genel olarak çocuğun yaşına bağlı olarak değişmektedir ve Tablo 1'de gösterilmiştir. 
Tablo 1. Yaş Gruplarına göre verilen çocuk ve gençlik yardımı miktarı

\begin{tabular}{|l|l|l|l|}
\hline Çocuk Yaşı & Çocuk Yardımı (vergiden muaf) & 3 Aylık & $\begin{array}{l}\text { Yıllık Toplam } \\
\text { Yardım Tutarı }\end{array}$ \\
\hline 0-2 yaş & DKK 14.5573 ayda bir (2019 yılı için) & 608 Euro & 2432 Euro \\
\hline 3-6 yaş & DKK 3.6093 ayda bir (2019 yılı için) & 481 Euro & 1924 Euro \\
\hline 7-14 yaş & DKK 2.8383 ayda bir (2019 yılı için) & 377 Euro & 1508 Euro \\
\hline 15-17 yaş & DKK 946 her ay (2019 yılı için) & 123 Euro & 1476 Euro \\
\hline
\end{tabular}

Ancak yapılan yardım miktarı ebeveynlerin gelirine bağlıdır. Diğer bir değişle, ebeveynlerin her birinin 782.000 DKK (105.000 Euro)'dan daha az bir gelire sahip olması halinde bu yardımdan tam olarak faydalanmaktadırlar. Çocuk ve gençlik yardımı Danimarka'da değişkenlik göstermekle beraber genellikle anneye verilmektedir. Eğer çocuk koruyucu ailede ise yardım koruyucu aileye ve evlat edinmek amacı ile çocuğu büyüten kişi/kişilere verilmektedir. Diğer taraftan eğer Udbetaling Danmark, çocuğun bu yardımı kendisi için doğru bir şekilde değerlendirebileceğine ikna olursa çocuğun kendisine verebilir.

\subsection{2. Çocuk Bakımı}

Çocuklar, bakım seçeneklerine, desteklerine ve bakım maliyetlerine göre gündüz bakım merkezlerine yerleştirilmektedir. Garantili gündüz bakım olanağı, çocuğun 26. haftasından (6 aylık) okul çağına kadar olan zaman dilimini kapsamaktadır. Böylelikle, çocuk bakım garantisi yardımı altında olan çocuklar, hafta içi her gün gündüz bakım merkezlerinden faydalanabilmektedir. Yerel yönetimler, çocuk bakım garantisi yardımını yerine getiremezse, aşağıdaki durumlarda masrafları ve hibeleri karşılamaktadır:

Başka bir yerel yönetim alanındaki gündüz bakım evinin masraflarını; Özel olarak işletilen çocuk bakım merkezinin bakım masraflarını; veya Ebeveynin kendi çocuğuna bakması için ebeveyne hibe verilmektedir. Çocuk bakım garantisi yardımına başvuru yapıldıktan sonra en geç 3 ay içinde sonuçlanmaktadır. Ancak, aşağıdaki kıstaslar geçerlidir:

131 Aralık 2019'da, 1 Euro = 7,49 Danimarka Kronu'na (DKK) eşittir. Kaynak:https://www.tcmb.gov.tr/wps/wcm/connect/TR/TCMB+TR/Main+Menu/ Istatistikler/Doviz + Kurlari/Gosterge + Niteligindeki+Merkez+Bankasi + Kurlarii/ 
Tablo 2. Gündüz bakım merkezindeki yaş ve katkı gruplaması

\begin{tabular}{|l|c|c|}
\hline & $\begin{array}{c}\text { Yerel Yönetimin } \\
\text { Minimum Katkısı }\end{array}$ & $\begin{array}{c}\text { Ailenin Maksimum } \\
\text { Katkısı }\end{array}$ \\
\hline Okul çağından küçük çocuklar & $75 \%$ & $25 \%$ \\
\hline $\begin{array}{l}\text { Okul çağındaki çocuklar } \\
\text { (örn. okul sonrasındaki oyun programı) }\end{array}$ & $70 \%$ & $30 \%$ \\
\hline
\end{tabular}

Yerel yönetimin yardımı, çocuğun yer aldığı gündüz bakım merkezine direk olarak ödenmektedir. Bu durum onaylanmış özel bir kurum için de geçerlidir. Yerel yönetimden ekonomik yardım alınması, aile gelirinde çocuğa ayrılan payın azalmasını sağlamaktadır. Ancak yerel yönetim bu kararı hane halkı gelirine göre değerlendirmektedir. Her iki ebeveyn çocukla birlikte yaşıyorsa, iki ebeveynin hane geliri temel alınarak yardımlar hesaplanmaktadır. Kısaca, çocuğun kayıtlı olduğu ebeveynin gelirine göre hesaplanmaktadır.

Tablo 3. Yerel yönetimin gündüz bakım merkezine verdiği destek

\begin{tabular}{|l|l|}
\hline Birleşik Hane Halkı Geliri (Aylık) & Ekonomik Desteğin Oranı (2019) \\
\hline $\begin{array}{l}\text { DKK 177.601'ün aşağısı } \\
(23.711 \text { Euro) }\end{array}$ & 100\% ekonomik destek \\
\hline $\begin{array}{l}\text { DKK 177.601 ile 181.538 } \\
(23.711-24.237 \text { Euro) arasında }\end{array}$ & $95 \%$ ekonomik destek \\
\hline $\begin{array}{l}\text { DKK 181.539 ile 551.699 } \\
(24.238-73.658 \text { Euro) arasında }\end{array}$ & $\begin{array}{l}\text { Ekonomik destek, gelirdeki her 3.852 DKK (514 } \\
\text { Euro)'lık artış için yüzde 1 puan düşürülür. }\end{array}$ \\
\hline $\begin{array}{l}\text { DKK 551.700 } \\
\text { (73.659 Euro) ve fazlası }\end{array}$ & 0\% ekonomik destek \\
\hline
\end{tabular}

\subsubsection{Annelik Yardımı}

Bir ebeveyn olarak işgücü piyasasıyla bir bağlantısı, bir başka ifadeyle sigortası varsa anne, hamilelik, doğum ve evlat edinme için doğum yardımı alabilmektedir. Ebeveynler 52 hafta boyunca birleştirilmiş doğum / babalık parası alma hakkına sahiptir. İlk birkaç hafta boyunca anne ve baba arasında sabit bir dağılım vardır, ancak ebeveynlerin son 32 haftalık izni kendi düzenleme seçeneği olacaktır. Hem anne hem de baba 32 haftalık (toplam 64 hafta) ebeveynlik iznine sahiptir ancak bu haftaların yalnızca 32'sinden yararlanma hakları bulunmaktadır. Bu hakların kullanımına ilişkin bilgiler Tablo 4'de gösterilmiştir. 
Tablo 4. Danimarka'ya ilişkin doğum izinleri

\begin{tabular}{|l|c|c|}
\hline Doğum durumunda yararlanma hakları & Anne & Baba \\
\hline Beklenen doğumdan 4 hafta önce & Hamilelik İzni & - \\
\hline $\begin{array}{l}\text { Doğumdan } 2 \text { hafta sonra (doğumdan sonraki ilk 14 } \\
\text { hafta içinde alınmalıdır) }\end{array}$ & - & Babalık İzni \\
\hline Doğumdan 14 hafta sonra & $\begin{array}{c}\text { Annelik İzni } \\
\text { (Süt İzni) }\end{array}$ & - \\
\hline Anne ve baba arasında 32 haftanın paylaşılması & Ebeveyn İzni & Ebeveyn İzni \\
\hline Evlat edinme durumunda yararlanma hakkı & Anne & Baba \\
\hline $\begin{array}{l}\text { Çocuğunuz yurtdışından kabul edildiyse, çocuğu almayı } \\
\text { beklemeden } 4 \text { hafta önce (özel durumlarda } \\
8 \text { haftaya kadar) } \\
\text { Çocuğunuz Danimarka'da kabul edilirse, çocuğu almayı } \\
\text { beklemeden } 1 \text { hafta önce (özel durumlarda } \\
2 \text { haftaya kadar) }\end{array}$ & Annelik İzni & Annelik İzni \\
\hline Çocuğu aldıktan 2 hafta sonra anne ve baba için & Annelik İzni & Babalık İzni \\
\hline \begin{tabular}{l} 
Çocuğu aldıktan 14 hafta sonra, sadece bir ebeveyn için \\
\hline Anne ve baba arasında 32 haftanın paylaşılması
\end{tabular} & Annelik İzni & Babalık İzni \\
\hline
\end{tabular}

Doğum yardımında alınan miktar ebeveynlerin maddi durumuna bağlı olarak değişmektedir. Ancak, vergilenmeden önce 2019 itibariyle haftada en fazla 4.355 DKK (584 Euro) alınmaktadır.

\subsection{Finlandiya}

Bu bölüm Avrupa Komisyonu (European Commission, 2019b, s.6-12) tarafından hazırlanan "Your social security rights in Finland" (Finlandiya'da sosyal güvenlik haklarınız) isimli rapordan derlenmiştir.

\subsection{1. Çocuk Yardımı}

Finlandiya'da çocuklu aileler, ailenin büyüklügüune göre çocuk yardımı (lapsilisä) almaktadır. Bu ödemeler Kela (Finlandiya Sosyal Sigortalar Kurumu) tarafından yapılmaktadır. 17 yaşın altındaki çocuklar için çocuk parası ödenmektedir. Çocuğun doğumunu izleyen ayın başından itibaren çocuk parası verilmektedir. Çocuk parası normal olarak anneye, babaya veya çocuğun bakımından sorumlu diğer bir yetişkine ödenebilir. Çocuk parası, çocuğun bakımından sorumlu başka bir kişiye ve bazı durumlarda çocuğa (15 yaşında veya 15 yaşından daha büyükse) ödenebilmektedir. 


\subsubsection{Küçüik Çocuklar İçin Bakım Desteği}

Ebeveynlik izni döneminden sonra aileler, çocuk okula başlayana kadar devlet gündüz bakım ödeneği, özel gündüz bakım ödeneği veya evde çocuk bakım ödeneği olmak üzere üç farklı sosyal yardım çocuk bakım alternatifine sahiptir: Ebeveynler, çocukları için belediyeye ait bir gündüz bakım evinden yararlanma hakkına sahiptir. Bir başka ifadeyle okul çağında olmayan bir çocuğun ebeveynlerinin ne kadar geliri olup olmadığına veya çalışıp çalışmadığına bakılmaksızın ebeveynler, çocukları için belediyeye ait gündüz bakım merkezinden yararlanma hakkına sahiptir. Belediye, ailenin büyüklüğüne ve gelirine göre günlük bakım için bir ücret almaktadır. En düşük gelirli ailelerden ücret alınmamaktadır. Aileler, çocuk okula başlamadan önce bir yıl boyunca çocukları için okul öncesi eğitimden de yararlanma hakkına sahiptir.

Belediyeye ait gündüz bakım merkezleri; gündüz bakım merkezi veya aile gündüz bakım merkezi olmak üzere ikiye ayrılmaktadır. Üç yaşın altındaki bir çocuk belediyeye ait gündüz bakım merkezine gitmezse, aile çocuk için evde çocuk bakım ödeneği talep edebilmektedir (kotihoidon tuki). Çocuğa ebeveynleri, akrabaları veya başka bir bakıcı da bakabilmektedir.

Özel gündüz bakım ödeneği (yksityisen hoidon tuki) ise, okul öncesi yaştaki çocuğa bakması için aile tarafından işe alınan bir dadı veya özel bir gündüz bakım görevlisi için talep edilebilmektedir. Anne veya baba üç yaşın altındaki bir çocuğa bakım sağlıyorsa ve haftada ortalama 30 saatten fazla çalışmıyorsa, esnek bakım ödeneği talep edebilirler (joustava hoitoraha). Son olarak, hane halkında ilkokul bir veya ikinci sınıfa devam eden çocuklar varsa ve ebeveynler haftada en fazla 30 saat çalışıyorlarsa, kısmi bakım ödeneği de talep edilebilir (osittainen hoitoraha).

\subsubsection{Annelik ve Babalık Yardımı}

Yeni doğum yapmış annelerin doğum hibesi (äitiysavustus) ve doğum izni (äitiysvapaa) ve babalık izni (isyysvapaa) hakkı bulunmaktadır. Bunlara ek olarak, her iki ebeveyn de ebeveyn izni alabilmektedir (vanhempainvapaa). Anneler, hamile olduklarında doğum paketi veya vergisiz bir toplu ödeme olarak 140 EUR (1 Haziran 2018'den 170 EUR) olarak doğum hibesi alırlar.

Doğum izni, en erken 50 iş günü ve en geç 30 iş günü içinde, tahmini son 2020/1 tarihten önce başlamaktadır. Doğum izni başladığında, Kela 105 iş günü boyunca doğum ödeneği (äitiysraha) ödemektedir. 
Anneler, hamilelik sırasında, eğer güncel analık ödeneği döneminden önce işten ayrılmaları gerekiyorsa, aşağıdaki nedenleri göstererek özel bir annelik ödeneği (erityisäitiysraha) talep edebilir:

Kimyasal maddelere, radyasyona veya bulaşıcı hastalıklara maruz kalmayı içeren bir işi varsa;

İş ortamındaki risk faktörleri kaçınılmazsa ve

İşveren hamilelik sırasında başka görevler düzenlemezse bu ödeneği alır.

Özel doğum ödeneği, güncel doğum ödeneklerini azaltmamaktadır.

Doğum ödeneği dönemi başlayana kadar ödenmektedir.

Babalar, çocuğun doğumundan sonra, en fazla 54 iş günü boyunca babalık izni alabilmektedirler. Baba en fazla 18 iş günü, yani yaklaşık üç hafta boyunca evde olabilmektedir. Babalık izni sırasında Kela (Finlandiya Sosyal Sigortalar Kurumu) bir babalık ödeneği (isyysraha) ödemektedir. Ebeveynlik izni doğum izninden sonra başlamaktadır. Ebeveynlik izni anne veya baba tarafından alınabilmektedir. Kela, 158 iş günü için ebeveyn ödeneği (vanhempainraha) ödemektedir.

Eğer ebeveynler 16 yaşın altında ağır hasta veya engelli bir çocuğa sahip ise ve çocuğu için düzenlenen tedaviye veya rehabilitasyona katılmak için geçici olarak iş başında bulunmazsa (maaş almıyor olması gerekiyor) özel bakım ödeneği (erityishoitoraha) talep edebilirler.

\subsection{Norveç}

Bu bölüm Avrupa Komisyonu (European Commission, 2019c, s.6-11): tarafından hazırlanan "Your social security rights in Norway" (Norveç'te sosyal güvenlik haklarınız) isimli rapordan derlenmiştir.

\subsubsection{Aile Yardımı}

\subsubsection{1. Çocuk Yardımı (barnetrygd)}

18 yaşından küçük bir çocuğu olan ve Norveç’te ikamet eden kişiler çocuk yardımı alabilmektedir. Bu ödemeler (Arbeids- og velferdsetaten) Norveç İşçi ve Refah Kurumu (Norwegian Labour and Welfare Administration NAV) tarafından yapılmaktadır. Buna ek olarak, Norveç'te çalışan, ancak ailesi başka bir Avrupa Ekonomik Bölgesi ülkesinde yaşayan biri de çocuk yardımı alma imkanına sahiptir. Çocuk Norveç'te doğmuşsa, büyük olasılıkla otomatik olarak ebeveyn çocuk yardımı almaktadır. Çocuk yardımı genellikle çocuğun annesine ödenmektedir. Eğer anne yerine başka bir hane halkı 
üyesine yardımın verilmesi gerekiyorsa, bu durumu değiştirmek için yetkili mercilere başvuru yapılması yeterlidir. Çocuk yardımı, çocuk 18 yaşına gelene kadar ödenmektedir. Ancak çocuk Norveç’te ikamet etmezse çocuk parası kesilmektedir.

Tablo 5. Norveç'te Çocuk Yardımı Parası

\begin{tabular}{|l|l|l|}
\hline Normal Çocuk Yardımı & Genişletilmiş Çocuk Yardımı & Bebek Desteği \\
\hline $\begin{array}{l}970 \text { NOK}^{2} \text { /aylık } \\
\text { (yaklaşık 100 Euro) }\end{array}$ & $\begin{array}{l}\text { +970 NOK (toplam 1.940) } \\
\text { (yaklaşık 200 Euro) }\end{array}$ & +660 NOK \\
\hline
\end{tabular}

\subsubsection{Geçici Yardım (Stønad til enslig mor eller far)}

Sekiz yaşından küçük çocuğu sahip tek ebeveynli aileler için geçici yardım bulunmaktadır. Bu yardımı alabilmek için evlenmemiş veya boşanmış olmak gerekmektedir. Evlilik dışı bir ilişkisi olup, ancak sekiz yaşından küçük çocuğun tek vasisi ise bu durumu belgelediği takdirde bu yardımdan yararlanabilmektedir. Söz konusu bu durumda yardım süresi, örneğin çocuğun özellikle ekstra bakıma ihtiyacı varsa ve bu da ebeveynin çalışmasını engelliyorsa, diğer bazı koşullar altında uzatılabilmektedir. Çocuğun eğitimi, çocuk bakıcısı ve taşınma masraflarını karşılamak için de yardım sağlanabilmektedir. Geçici yardım parası yıllık 2,25G ${ }^{3}$ (Ulusal Sigorta Temel Tutarı) veya 1 Mayıs 2018 itibarıyla 217.987 NOK (yaklaşık 22.000 Euro)'ya eşittir.

\subsubsection{Küçüik Çocuklu Aileler İçin Nakit Yardım (Kontantstøtte)}

1-2 yaşları arasında çocuğu olan ve gündüz bakım merkezlerinde yerin olmaması durumunda küçük çocuklu aileler nakit yardımı alabilmektedir. Bu yardımı alabilmek için bazı koşulların sağlanması gerekmektedir. Öncelikle, çocuk Norveç'te ikamet etmelidir. Yardım, 13 ay ile 23 ay arasındaki çocukların ebeveynlerine verilmektedir. Ebeveynlerin, 1 Temmuz 2017'den itibaren ödenek alanın Ulusal Sigorta Sistemine en az 5 yıllık bir üyeliği olması gerekmektedir. Çocuk her iki ebeveyni ile birlikte yaşıyorsa, bu gereksinim her ikisi için de geçerlidir. 2018 yılında, küçük çocukları olan aileler için nakit yardım ayda 7.500 NOK (753 Euro)'dur. Eğer çocuk

\section{8}

Çocuk ve Medeniyet 2020/1
231 Aralık 2019'da, 1 Euro = 9,95 Norveç Kronu'na (NOK) eşittir.

31967 yılına dayanan Ulusal Sigorta programı temel miktarını ifade etmektedir. Vergi düzenlemeleri, genellikle ' $G$ ' olarak yazılır ve Ulusal Sigorta programındaki temel miktara doğrudan bağlı olan bir dizi tutar ve tutar limiti içerir. Ayrıntılı bilgi için https://www. skatteetaten.no/en/rates/national-insurance-scheme-basic-amount/ 
gündüz bakım merkezine giderse yardımın hepsi alınamaz. Çocuk gündüz bakım merkezinde yarı zamanlı giderse, yardımlar aşağıdaki gibi sağlanır:

Tablo 6. Norveç’te Gündüz Çocuk Merkezindeki Geçirilen Süre ve Yardımdan Ödenen Pay

\begin{tabular}{|l|l|}
\hline Haftalık geçirilen Süre (saat) & Yardım payı \\
\hline 8 ve altı & $\% 80$ \\
\hline $9-16$ & $\% 60$ \\
\hline $17-24$ & $\% 40$ \\
\hline $25-34$ & $\% 20$ \\
\hline
\end{tabular}

\subsubsection{Hamilelik, Doğum ve Evlat Edinme İçin Yardımlar}

\subsubsection{Hamilelik Yardımı}

Karnında taşıdığı çocuk nedeniyle veya kadının kendi sağlığı için bir risk nedeniyle kadın çalışamıyorsa, hamilelik yardımı sağlanmaktadır. Örneğin, hamile bireyin çalışması fiziksel olarak zorlayıcı veya stresli olduğu durumda veya kimyasal maddelerle veya tehlikeli araçlarla çalıştığı durumda bu yardımdan faydalanabilir. Bu durumun kendisi ve fetüs için sakınca yaşatacağı görüşüne sahipse ve ayrıca işverenin hamile bireye daha uygun görevler tahsis edemediğini gösteren belgelerle ve bir doktordan veya gebelik ve doğum danışmanından bir belgeyle hamilelik yardımına başvuru yapilabilmektedir.

Hamilelik yardımı hastalık parası ile aynı şekilde hesaplanmaktadır. Gelirin yüksek olup olmadığına bakılmaksızın, maksimum yardım yıllık 6G'ye eşittir; bu, geçerli Temel Gelir (G) kullanılarak NOK 581.298 (yaklaşık 60.000 Euro)'dir. Hamilelik yardımı, doğumdan üç hafta öncesine kadar çalışmayı bıraktıktan sonra alınabilmektedir.

\subsubsection{Ebeveynlik yardımı}

Ebeveynlik yardımının alınabilmesi için öncelikle hamile ya da evlat edinme yolu ile çocuk sahibi olan ebeveynin son 10 ayın 6 ayında çalışmış olması gerekmektedir. Söz konusu bu durum hastalık parası, iş değerlendirme ödeneği, ebeveyn parası vb. için de geçerlidir. Ebeveynlik yardım süresi \%100 kapsam içinde (sigortadan ya da devletten yardımın tamamı karşılanıyor) 49 hafta (her ebeveyn için 15 hafta ayrılmıştır) veya \%80 kapsam içinde 59 hafta (her ebeveyn için 19 hafta ayrılmıştır) olarak belirlenmiştir. Ebeveynlik yardımı doğumdan üç hafta önce anne için 
ayrılmıştır (bunlar anne kotasının bir parçası değildir). Bu 3 hafta evlat edinme için geçerli değildir, evlat edinme durumunda toplam süre 46 veya 56 haftaya gelmektedir.

Belirli koşullar altında, çocuk 3 yaşına gelene kadar ebeveyn yardımı alınabilmektedir. Bu yardımın alınabilmesi için yıllık bazda ebeveyn gelirinin en az 0,5G yani 1 Mayıs 2018 itibarıyla 48.422 (yaklaşık 5.000 Euro) NOK'ya eşit olması gerekmektedir.

\subsubsection{Doğum veya evlat edinme için toplu ödeme}

Çocuğu olan, ancak ebeveyn yardımı alma hakkını kazanmamış kadınlara toplu halde hibe yapılmaktadır. 2018'de, toplu ödeme hibe çocuk başına 83.140 NOK (yaklaşık 8.500 Euro)'dur.

\section{4. İsveç}

Bu bölüm Avrupa Komisyonu (European Commission, 2019d, s.6-19): tarafından hazırlanan "Your social security rights in Sweden" (İsveç’te sosyal güvenlik haklarınız) isimli rapordan derlenmiştir.

\subsection{1. Çocuk Ödeneği}

İsveç'te yaşayan ve çocuk sahibi olan herkes, çocuk parası alma hakkına sahiptir. Bu ödemeler İsveç Sosyal Güvenlik Ajansı (Swedish Social Insurance Agency) tarafindan yapılmaktadır. Bu, doğumdan sonraki birinci ay ve çocuk 16 yaşına kadar dahil tüm ebeveynlere otomatik olarak ödenen finansal destektir. Daha sonra genişletilmiş çocuk ödeneği veya öğrenci hibesi imkanları da bulunmaktadır. Birden fazla çocuğu olan aileler çocuk ödeneğinin dışında büyük aile ödeneğinden de yararlanabilmektedir. Söz konusu yardımlara yönelik Avrupa Birliği (AB) vatandaşları için özel uygulama programları bulunmaktadır. Çocuk ödeneği, genişletilmiş çocuk ödeneği ve büyük aile ödeneği vergiden muaf desteklerdir. Buna ek olarak, çocuğun iki vasisi varsa çocuk yardımı ebeveynler arasında paylaşılmaktadır. Bir vasi varsa, sadece bu kişiye çocuk yardımı ödenmektedir. Çocuk ödeneği ayda $1.250 \mathrm{SEK}^{4}$ (120 Euro) veya iki vasi varsa her bir ebeveyn için 625 SEK olarak belirlenmiştir.

\subsubsection{Genişletilmiş Çocuk Ödeneği}

İsveç'te bir çocuk 16 yaşına ulaştıktan sonra uzatılmış ödenek alma imkanına sahiptir. Çocuk lisede okuyorsa, İsveç Öğrenci Finans Kurulu 
(CSN) çocuğa bir çalışma ödeneği ödemektedir. İlk ödeme, çocuğun 16 yaşından sonraki çeyrekte son bankacılık gününde yapılmaktadır. Bu hibe, çocuk 20 yaşını doldurduğu yılın Haziran ayına kadar ödenmektedir. Çocuk hala zorunlu olarak okulda veya okuyorsa, İsveç Sosyal Sigorta Kurumu, çocuğun kursu tamamladığı veya çalışmaları sona erdirdiği aya kadar (bu süre dahil) uzatılmış çocuk ödeneği ödemektedir.

\subsubsection{Geniş Aile Ödeneği}

Birden fazla çocuğu olan bir ailede, çocuklar 16 yaşına gelene kadar büyük aile desteği ve çocuk ödeneği alma imkanına sahiptir. 16 yaşından büyük olan çocuklar ailesi ile birlikte yaşıyorsa, evli değilse ve tam zamanlı eğitim görüyorsa 20 yaşını doldurana kadar destek alabilir.

\subsubsection{Bakım Desteği}

Ayrı bölümlerde açıklanan ebeveyn ve çocuk ödeneğine ek olarak, ebeveynlerin başka çeşitli yardım türlerine de sahip olduğu görülmektedir. Hasta bir çocuğa bakmak için ebeveynler çalışmıyorlarsa ve evde kalması gerekiyorsa, ebeveynler geçici ebeveyn yardımından yararlanabilirler. Eğer ebeveynler birlikte değilse, diğer ebeveyn çocuğun masraflarına katkıda bulunmuyorsa bakım desteği alması mümkündür. Tek başına yaşayan ve evlat edinen bir ebeveynin de, bakım desteği alma olanağı bulunmaktadır. Evlat edinmeye ilişkin toplu ödeme alınması mümkündür. Engelli bir çocuğunuz varsa, diğer yardımlardan da yararlanma hakkınız olabilir.

Bir çocuk sadece bir ebeveyni ile birlikte yaşıyorsa, diğer ebeveyni çocuğun desteğine katkı olarak bakım parası ödemek zorundadır. Bunun gerçekleşmediği durumlarda, çocuk bakım desteği alma hakkına sahip olabilmektedir. Ailenin durumuna bağlı olarak farklı bakım desteği türleri bulunmaktadır. Bu destek çocuğun yaşadığı ve kayıtlı olduğu ebeveyne ödenmektedir.

Bakım desteğinin miktarı çocuğun kaç yaşında olduğuna bağlı olarak değişmektedir: Çocuk 0-10 yaş aralığında ise, bakım desteği ayda çocuk başına maksimum 1.573 SEK (150 Euro)'dir; çocuk 11-14 yaş aralığında, çocuk başına aylık 1.723 SEK (165 Euro); ve çocuk 15 yaşında veya daha büyükse, bu tutar 2.073 SEK (yaklaşık 200 Euro)'dir.

\subsubsection{Evlat Edinme Hibesi}

Evlat edinen ebeveyn, istediği taktirde evlat edinme hibesi alabilmektedir. Ancak evlat edinme, Aile Hukuku ve Ebeveyn Destek Ajansı veya bir İsveç mahkemesi tarafından onaylanmalıdır. Yabancı bir çocuğu evlat edinme 
kararı da bu hibeyi almak için yeterli olmaktadır. Evlat edinme hibesi her çocuk için 75.000 SEK (yaklaşık 7.200 Euro) ve bu tutar vergiden muaftır (Ocak 2017'den önce kabul edilen çocuklar için bu miktar 40.000 SEK'dir).

\subsubsection{Ebeveynlik Yardımları ve Doğumla İlgili Yardımlar}

Ebeveynlik yardımı, çalışmak, iş aramak ya da eğitim görmek yerine çocukları ile evde kalabilmek için alınan yardım türlerinden biridir. Her iki ebeveyn çocuk başına toplam 480 günlük ebeveyn yardımı almaktadır. Birden fazla doğum durumunda, her ilave çocuk için 180 gün daha verilmektedir. Ebeveynlik yardımı, ebeveyn başına 240 gün ve ebeveynler arasında 480 günün dağıtılmasıyla oluşur. Günde minimum 180 SEK (17 Euro) alınmaktadır. Çocuğun annesi beklenen doğumdan 60 gün önce ebeveyn parası almaya başlayabilmektedir. Kural olarak, aynı koşullar evlat edinenler için de geçerlidir. Bu süreçte yapılan ebeveyn sigortası vergiye tabi olmaktadır. Fiziksel olarak yorucu veya tehlikeli bir işi olan ebeveyn varsa, hamileyken hamilelik nakit parası için başvuru yapabilme hakkına sahiptir. Hasta bir çocuğa bakmak için ebeveynlerin işe gidememe ve evde kalma durumu gerekiyorsa geçici ebeveyn yardımı alabilirler.

\section{Sosyal Demokrat Refah Devletlerine İlişkin Çocuk Yoksulluğuna Yönelik İstatistikler}

Bu bölümde sosyal demokrat refah devletlerine ilişkin çocuk yoksulluğuna yönelik istatistikler bulunmaktadır. Çocuk yoksulluğu istatistiğinin (eşdeğer hane halkı kullanılabilir medyan gelirin \%60'ını dikkate alınarak belirlenen yoksulluk sınırı) yanı sıra, sosyal dışlanma ve maddi yoksunluk istatistikleri ile ülkelerin sosyal harcamaya ve özellikle aile ve çocuğa kişi başına ne kadar harcadığı ve Gayri Safi Yurtiçi Hasıla (GSYH) içinden ne kadar para ayırdı̆̆ı da incelenecektir.

Tablo 7, toplam nüfus ve $\mathbf{0 - 1 8}$ yaş grubuna ilişkin sosyal demokrat refah devletlerine ait çocuk yoksulluğu veya sosyal dışlanma, çocuk yoksulluğu ve maddi yoksunluğa ilişkin istatistikleri ve sıralamaları sunulmaktadır. Tablo 7'ye bakıldığında, 2017 verilerine göre AB-275'deki nüfusun \%22,5'i

5 Tablo 7 ve Tablo 8'de elde edilen veriler AB 27'nin yanı sıra (Almanya, Avusturya, Belçika, Bulgaristan, Çekya, Danimarka, Estonya, İrlanda, Yunanistan, İspanya, Fransa, Italya, Kıbris, Letonya, Litvanya, Lüksemburg, Macaristan, Malta, Hollanda, Polonya, Portekiz, Romanya, Slovenya, Slovakya, Finlandiya, İsveç ve İzlanda), Avrupa Bölgesinde bulunan ancak AB'ye üye olmayan ülkeleri de (Birleşik Krallk, Norveç, Türkiye, İsviçre, Karadağ, Kuzey Makedonya, Sirbistan ve Bosna Hersek) içermektedir (toplamda 36 ülke). 
Tablo 7. Toplam nüfus ve 0-18 yaş grubuna ilişkin Sosyal Demokrat Refah Devletlerine ait çocuk yoksulluğu veya sosyal dışlanma, çocuk yoksulluğu ve maddi yoksunluğa ilişkin istatistikler ve sıralamaları

\begin{tabular}{|l|c|c|c|c|c|c|c|c|c|c|c|c|}
\hline & \multicolumn{5}{|c|}{ Toplam } & \multicolumn{6}{|c|}{18 yaş altı } \\
\hline 2017 & $\begin{array}{c}\text { Y\&SD } \\
\%\end{array}$ & Sıra & $\begin{array}{c}\text { Y } \\
\%\end{array}$ & Sıra & $\begin{array}{c}\text { MY } \\
\%\end{array}$ & Sira & $\begin{array}{c}\text { Y\&SD } \\
\%\end{array}$ & Sira & $\begin{array}{c}\text { Y } \\
\%\end{array}$ & Sıra & $\begin{array}{c}\text { MY } \\
\%\end{array}$ & Sira \\
\hline AB-27 & 22,5 & & 16,9 & & 6,9 & & 24,5 & & 20,0 & & 7,3 & \\
\hline Danimarka & 17,2 & 8. & 12,4 & 4. & 3,1 & 7. & 14,5 & 2. & 10,0 & 1. & 3,1 & 7. \\
\hline Finlandiya & 15,7 & 2. & 11,5 & 2. & 2,1 & 4. & 15,1 & 4. & 10,2 & 2. & 1,8 & 3. \\
\hline İsveç & 17,7 & 9. & 15,8 & 15. & 1,1 & 1. & 19,4 & 10. & 18,6 & 16. & 0,9 & 1. \\
\hline Norveç & 16,0 & 3. & 12,3 & 3. & 2,3 & 5. & 16,4 & 5. & 13,7 & 5. & 2,9 & 6. \\
\hline
\end{tabular}

Kaynak: www.ec.europa.eu/eurostat (Eurostat, 2020) sitesinden elde edilen veriler kullanılarak tarafımca hazırlanmıştır.

Y\&SD: Yoksulluk veya Sosyal Dışlanma

Y: Yoksulluk

MY: Maddi Yoksunluk

yoksulluk veya sosyal dışlanmaya maruz kalmaktadır. Ancak Danimarka, Finlandiya, İsveç ve Norveç'in AB-27'ye göre yoksulluk veya sosyal dışlanmaya daha az maruz kaldığı görülmektedir. AB-27'deki nüfusun \%16,9'u yoksulluk çekmektedir. AB-27'deki nüfusun \%6,9'u maddi yoksunluk yaşamaktadır. Maddi yoksunluk konusunda İsveç’in birinci sırada yer aldığı, başka bir deyişle maddi yoksunluğu en az görülen Avrupa ülkesi olduğunu söyleyebiliriz.

Diğer taraftan, AB-27'deki 0-18 yaş arasındaki çocukların \%24,5'i yoksulluk veya sosyal dışlanma çekmektedir. Ancak Danimarka, Finlandiya, İsveç ve Norveç'te AB-27'ye göre 0-18 yaş arasındaki çocuklar yoksulluk veya sosyal dışlanmayı daha az yaşamaktadırlar. AB-27'deki 0-18 yaş arasındaki çocukların \%20'si yoksulluk çekmektedir. Danimarka, 0-18 yaş arasındaki çocukların yoksulluk oranı en iyi durumda olan ülkedir. AB-27'deki 0-18 yaş arasındaki çocukların \%7,3'ü maddi yoksunluk yaşamaktadır. 0-18 yaş arasındaki çocukların maddi yoksunluk oranı İsveç için en iyi durumdadır.

Tablo 8, sosyal demokrat refah devletlerinin sosyal korumaya, aile ve çocuğa ayırdıkları kişi başına Euro miktarı ve GSYH'den ayırdıkları yüzdeyi sunmaktadır. AB-27'de sosyal korumaya kişi başı düşen miktar 7.342,89 
Tablo 8. Sosyal demokrat refah devletlerinin sosyal korumaya ve aile ve çocuğa ayırdıkları kişi başına Euro miktarı ve GSYH'den ayırdığı pay

\begin{tabular}{|c|c|r|r|r|r|r|r|r|}
\hline & \multicolumn{4}{|c|}{ Sosyal Koruma } & \multicolumn{4}{c|}{ Aile ve Çocuk } \\
\hline & $\begin{array}{c}\text { Kişi Başına } \\
\text { Düşen Miktar } \\
\text { (Euro) }\end{array}$ & Sıra & $\begin{array}{c}\% \\
\text { GSYH }\end{array}$ & Sira & $\begin{array}{c}\text { Kişi Başına } \\
\text { Düşen Miktar } \\
\text { (Euro) }\end{array}$ & Sira & $\begin{array}{c}\% \\
\text { GSYH }\end{array}$ & Sıra \\
\hline AB-27 & $7.342,89$ & & 26,9 & & 628,84 & & 2,3 & \\
\hline Danimarka & $14.680,26$ & 4. & 30,8 & 2. & $1.638,02$ & 3. & 3,4 & 1. \\
\hline Finlandiya & $11.056,59$ & 6. & 30,1 & 3. & $1.083,33$ & 6. & 2,9 & 6. \\
\hline İsveç & $12.179,94$ & 5. & 28,2 & 6. & $1.236,79$ & 4. & 2,9 & 5. \\
\hline Norveç & $18.429,46$ & 1. & 27,9 & 8. & $2.138,99$ & 2. & 3,2 & 4. \\
\hline
\end{tabular}

Kaynak: www.ec.europa.eu/eurostat (Eurostat, 2020) sitesinden elde edilen veriler kullanılarak tarafımca hazırlanmıştır.

kişi başına sosyal korumaya ayırdığı 18.429,46 Euro ile birinci sırada yer almaktadır. AB-27'de aile ve çocuğa ayrılan kişi başı miktar 628,84 Euro'dur. Bu miktar AB-27'nin GSYH'nin \%2,3'nü oluşturmaktadır. Aile ve çocuğa ayrılan kişi başı 1.638,02 Euro ile Danimarka, GSYH'sinin \%3,4'ünü ayırarak birinci sırada yer almaktadır. Sosyal demokrat refah devletleri, hem sosyal korumaya harcadıkları kişi başına düşen miktar bakımından hem de GSYH'den ayırdığı yüzde bakımından AB-27 ortalamasından fazladır. Buna ek olarak, aile ve çocuğa harcadıkları kişi başına düşen miktar bakımından, hem de GSYH'den ayırdığı oran bakımından AB-27 ortalamasından yine fazladır.

\section{Sonuç}

Ülkeleri ve devletleri sınıflayan ve değişime uğratan savaşlar, krizler ve teknolojik atılımlardır. Özellikle İkinci Dünya Savaşı'ndan sonra devletler, öncelikle eğitim ve sağlık olmak koşuluyla, sosyal güvenliğe ve sosyal korumaya önem vermişlerdir. Bu çalışmanın da konusu olan, sosyal demokrat refah devletleri bu unsurları önceleyen ve iyi bir şekilde uygulayan refah devletleri olarak karşımıza çıkmıştır.

Sosyal demokrat refah devletlerinin sosyal korumaya, aile ve çocuğa yönelik uyguladığı politikalar ve programlar diğer devletler açısından ütopik gözükse de koruyucu ve önleyici bir yol izleyerek özellikle 0-18 yaş grubunu öncelemişlerdir. Sosyal demokrat refah devletlerinin aileye ve çocuklara yaptığı yardımlar, sunduğu ödenekler ve hibeler toplumun sağlıklı bir 
şekilde inşasını sağlamaya yöneliktir. Özellikle bu devletler sosyal korumaya ayırdıkları GSYH içindeki pay ve kişi başına düşen miktar bakımından, diğer Avrupa bölgesindeki ülkelerden farkını apaçık ortaya koymaktadır. Sadece ayırdıkları kişi başına düşen miktarı ve GSYH içindeki pay değil, uygulamaya koydukları sosyal programlar yönüyle de diğer ülkelerden ayrıldı̆̆ı söylenebilir.

Sosyal demokrat refah devletlerinde, çocukların okuması ve sağlıklı gelişebilmesi için çocuklara yönelik 'maddi olanaklar' ve doğum öncesinde, doğum sırasında ve doğum sonrasında, buna ek olarak engelli bir çocuğu varsa ebeveynlere verilen 'izinler' bugüne kadar karşılaşılmayan biyopsikososyal ${ }^{6}$ bir modelin göstergesidir. Bu refah devletlerinin insanlara yaşamaları için minimum standartları dayatmaları yerine, insan onuruna yakışır bir şekilde bir yaşam sunma politikası bulunmaktadır.

Öte yandan, sosyal demokrat refah devletlerinde nüfusun yaşlanmakta olduğu bilinmektedir. Bu bağlamda devletlerin hem anne ve babaya doğum için verdikleri izin süresi bakımından hem de yardımların, ödeneklerin ve hibelerin miktarı, insanları çocuk sahibi olmaya yönlendirme amaçlıdır.

İskandinav ülkelerinin, çocuk yoksulluğunu veya yoksulluk içinde yaşayan çocukların sorunlarını çocukken çözülmesi gerektiğini düşündüklerini ve bunu uygulamaya döktüklerini görmekteyiz. Eğer çocukluk çağında, çocukları örseleyen, dişlayan ve yoksunluk çekmesine neden olan sorunlar ortadan kaldırılmadığı takdirde çocukların ilerleyen yıllarda hem yoksulluğu hem de yoksunluğu yetişkin olarak da çekmesi büyük olasılıktır. Bu bağlamda, İsveç, İskandinav ülkelerinin birazcık aritmetiğini bozsa da İskandinav ülkelerinde yaşayan çocukların yoksulluğu, sosyal dışlanmayı ve maddi yoksunluğu, diğer AB ülkelerine göre daha az yaşadığını ifade edebiliriz.

Her krizde sosyal refah devletlerinin gücü ve itibarı konuşulur olmuştur. En son Covid-19 virüs salgınında da olduğu gibi refah devletlerinin güvenilirliği tekrardan sorgulanmaya başlanmıştır. Buna ek olarak, refah seviyesinin getirmiş olduğu rahatlık sonucu önlemler de geç alınmış olabilir. Bu dönemi Koray (2012, s.74) sosyal refah devletlerinin kendilerini sorgulama ve yeniden biçimlenme dönemi olarak görmektedir. Buna ek olarak, Harari (2019, s.59) ise bu sorgulamay1 "Insanlar binlerce ynl boyunca otoritenin insan yüreğinden değil kutsal kanunlardan geldiğine ve dolayısıyla insanın özgürlüğünü değil Tanrı kelamını kutsamamız gerektiğine inandı. Otoritenin kaynağı sadece 
birkaç yüzyıl önce semai Tanrlardan çıkıp etten ve kemikten insanlara aktarıldı" ifadesiyle açıklamış ve bu otoritenin gelecekte algoritmalara bir başka ifadeyle bilgisayarlara aktarılacağını ifade etmiştir.

Sonuç olarak bu dönüşüm ilk başta emekten sermayeye dönmüş, önümüzdeki yıllarda ise sermayeden teknolojiye dönüşebilir. Emekten sermayeye dönüşüm sürecinde, bu sürece adapte olan devletler yaşadığımız çağın sosyal refah devletleri olduğu söylenebilir. Sermayeden teknolojiye dönüşüm sürecinde sosyal refah devletleri koruma ve önleyici önlemler almaz ise -çocukların günümüz şartlarında eşit, adil ve yeterli eğitim alamaması, çağa ayak uydurabilmeleri için muazzam bir enerji harcaması, çocuklar için boş zaman değerlendirmenin öneminin artması vb.- konumunu kaybedebilir. Bu durumda, teknolojinin merkezinde çocukların olması ve 21 . yüzyılın teknoloji ve çocuk çağı olarak anılması kaçınılmazdır.

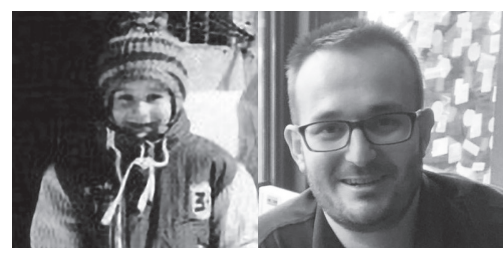

\section{Ercem Erkul}

\section{Kaynakça}

Alcock, P., May, M., \& Rowlingson, K. (2008). Sosyal Politika Kuramlar ve Uygulamalar. Ankara: Siyasal Kitapevi.

Borger. (2020, 07 16). Benefits from Udbetaling Danmark. https://www.borger.dk/kampagnesider/ udbetaling-danmark-english\#js-anchor-32117a0d-050a-4458-84ba-7119eb13247a adresinden alındı.

Esping-Andersen, G. (1990). The three worlds of welfare capitalism. Princeton University Press.

European Commission. (2019a). Your social security rights in Denmark. Employment, Social Affairs \& Inclusion: https://ec.europa.eu/social/main.jsp?catld=1107\&langld=en 2 Mayıs 2020 tarihinde adresinden alındı.

European Commission. (2019b). Your social security rights in Finland. Employment, Social Affairs \& Inclusion: https://ec.europa.eu/social/main.jsp?catld=1109\&langld=en 2 Mayıs 2020 tarihinde adresinden alındı.

European Commission. (2019c). Your social security rights in Norway. Employment, Social Affairs \& Inclusion: https://ec.europa.eu/social/main.jsp?catld=1123\&langld=en 2 Mayıs 2020 tarihinde adresinden alındı.

European Commission. (2019d). Your social security rights in Sweden. Employment, Social Affairs \& Inclusion: https://ec.europa.eu/social/main.jsp?catld=1130\&langld=en 2 Mayıs 2020 tarihinde adresinden alındı.

Çocuk ve Medeniyet 2020/1
Eurostat, (2020), At-risk-of-poverty rate by poverty threshold, age and sex-EU-SILC and ECHP surveys, http://appsso.eurostat.ec.europa.eu/nui/show.do?dataset=ilc_li02\&lang=en. Erișim tarihi 05.02.2020 
Eurostat, (2020), People at risk of poverty or social exclusion - <http://appsso.eurostat.ec.europa.eu/ nui/show.do?dataset=ilc_peps01\&lang=en>, Erișim tarihi 05.02.2020

Eurostat, (2020), Severe material deprivation rate by age and sex - $h$ ttp://appsso.eurostat.ec.europa. eu/nui/show.do?dataset=ilc_mddd11\&lang=en Erișim tarihi 05.02.2020

Harari, Y. N. (2019). 21.Yüzyıl için 21 Ders. İstanbul: Kolektif Kitap.

Koray, M. (2012). Sosyal Politika. Ankara: Imge Kitapevi.

Șenses, F. (2014). Küreselleșmenin Öteki Yüzü Yoksulluk. İstanbul: İletișim Yayınları.

UNICEF (2001). Child-centered Development: the basis for Sustainable Human Development. Newyork: UNICEF.

WHO. (2020, 07 16). WHO remains firmly committed to the principles set out in the preamble to the Constitution: https://www.who.int/about/who-we-are/constitution\#: :text=Health\%20is\%20 a\%20state\%20of,absence\%20of\%20disease\%20or\%20infirmity.\&text=The\%20health\%20of\%20 all\%20peoples,operation\%20f\%20individuals\%20and\%20States. adresinden alındı. 


\section{Hangisi Doğru?}

Uzaktan okul sanal bir alemde Evimize gelse de Özledik sınıf kokusunu Öğretmenlerimizi Arkadaşlarımızla Göz göze gelmeyi özledik

Her gün gittiğimiz yolu Teneffüs zilini

Ağır okul çantamızı özledik

-Alışın uzaktan okula

Dese de büyüklerimiz

Güzel değildir

Uzaktan

Şarkı söylemek bile

Mustafa Ruhi Şirin 